\title{
Livestock effects on reproduction of the Columbia spotted frog
}

\author{
EVELYN L. BULL AND MARC P. HAYES
}

Authors are research wildlife biologist, Pacific Northwest Research Station, 1401 Gekeler Lane, La Grande, Ore. 97850, ebull@fs.fed.us, and adjunct assis tant professor, Department of Biology, Portland State University, Portland, Ore. 97207-0751.

\begin{abstract}
We evaluated reproduction and recruitment of the Columbia spotted frog (Rana luteiventris Thompson) in 70 ponds used by beef cattle and in 57 ponds not used by beef cattle in northeastern Oregon. No significant differences were detected in the number of egg masses or recently metamorphosed frogs in grazed and ungrazed sites. No pond characteristic measured could predict egg mass numbers, but percent aquatic vegetation and dissolved oxygen had some ability to predict recently metamorphosed frog numbers. Both variables explained $65 \%$ of the variability in recently metamorphosed frog numbers in grazed ponds. At ungrazed ponds, 4 additional variables (presence of fish, elevation, percent of rock, and conductivity) were required to achieve the same level of variability in predicting recently transformed frog abundance. The egg mass volume was larger at grazed than at ungrazed ponds suggesting that grazed ponds may have a greater food abundance or larger (older) individuals.
\end{abstract}

Key Words: livestock grazing, northeastern Oregon, Rana luteiventris Thompson

Global amphibian declines have precipitated the need to determine the status of many amphibian populations and identify factors influencing those populations. The recently described Columbia spotted frog (Rana luteiventris Thompson) (Green et al. 1997) is known to reproduce in and occupy aquatic habitats associated with riparian zones (Turner 1960) and has experienced some declines within its range (Hovingh 1993, Munger et al. 1996). Grazing is a prominent feature in many of these aquatic ecosystems, including northeastern Oregon (Kauffman et al. 1983, Green and Kauffman 1995). The influence of livestock on the physical characteristics (Bohn and Buckhouse 1986), vegetation (Roath and Krueger 1982, Sedgewick and Knopf 1991, Allen and Marlow 1994), fishes (Platts 1981), and avifauna (Thomas et al. 1979, Mosconi and Hutto 1982) in riparian ecosystems is reasonably well studied and could influence spotted frog habitat. Beyond discussions of potential impacts (Horusp et al. 1993, Jennings and Hayes 1994, Hayes 1997), the influence of livestock

Thad W. Heater, Karen L. Gray, Janet E. Hohmann, Karen Kronner, Chris Pearl, and Jay F. Shepherd assisted with field work. The following private land owners allowed us to search for frogs on their property: Vic Coggans, Cunningham Sheep Co., Margarite Fahrenwald, Eastern Oregon Agricultural Research Center, La Grande Rifle and Pistol Club, Doug McDaniel, Nevada First Corp., Bob Schiller (deceased), Nyoda Scott, and Dick Snow.

Manuscript accepted 19 Aug. 1999.
Resumen

Evaluamos la reproducción y la iniciación de la rana "Columbia spotted" (Rana luteiventrisi Thompson) en 70 estanques utilizados por ganado bovino para carne y en 57 estanques no utilizados por bovinos para carne localizados en el nordeste de Oregon. No se detectaron diferencias significativas en el numero de masas de huevecillos o de ranas recientemente metamorfoseadas entre los sitios con y sin apacentamiento. Las características de los estanques que fueron medidas no pudieron predecir el numero de masas de huevecillos, pero el porcentaje de vegetación acuática y el oxigeno disuelto tienen cierta capacidad para predecir los números de ranas recientemente metamorfoseadas. Ambas variables explicaron el $65 \%$ de la variabilidad de ranas recientemente metamorfoseadas en los estanques de sitios con apacentamiento. En estanques de sitios sin apacentamiento, 4 variables adicionales (presencia de peces, elevación, porcentaje de rocas y conductividad) se requirieron para lograr el mismo nivel de variabilidad para predecir la abundancia de ranas recientemente transformadas. El volumen de la masa de hevecillos fue mayor en los estanque de sitios con apacentamiento que en los de sitios sin apacentamiento, lo que sugiere que en los estanques de áreas con apacentamiento puede haber una mayor abundancia de alimento o individuos mas viejos.

on amphibians has been only recently addressed. In southwestern Idaho, Munger et al. (1994) found that sites with adult Columbia spotted frogs had significantly less grazing pressure than sites without spotted frogs, but he found no differences in a subsequent year (Munger 1996).

This paper describes our preliminary assessment of the relationship between grazing and the Columbia spotted frog in northeastern Oregon. Using the number and volume of egg masses and number of recently metamorphosed juveniles to assess spotted frog reproduction and recruitment, respectively, we measured biotic and abiotic variables at 127 breeding sites of Columbia spotted frogs to determine differences between grazed and ungrazed sites.

\section{Methods}

Egg Masses (Reproduction)

We searched for Columbia spotted frog breeding sites in 5 major watersheds (Grande Ronde River, Eagle Creek, John Day River, Malheur River, and Wallowa River) in Union, Umatilla, Baker, Grant, and Wallowa counties. Spotted frogs were known 
to occur in these watersheds based on historical records (Ferguson 1952, 1954; Ferguson et al. 1958; unpublished data on file at Pacific Northwest Research Station, La Grande, Ore.). We selected specific watersheds to search based on several criteria: presence of a perennial stream with quiet water in the form of ponds, marshes, and backwaters nearby; streams with a wide valley bottom $(<10 \%$ gradient $)$ and open meadows adjacent to coniferous forests (forest types of ponderosa pine [Pinus ponderosa Dougl. ex Laws], lodgepole pine $[P$. contorta Dougl. ex Loud], or mixed conifer); within $2 \mathrm{~km}$ of a road; and on public land or on private land for which we had permission to search. Beef cattle grazing occurred in some of each watershed sometime between June and October, although significant portions of each watershed were currently ungrazed. Grazing systems had typically been in place within each watershed for at least 5 years.

We searched for egg masses between 22 March and 20 May 1997. The date a particular site was searched depended on water temperature. We conducted 1 search at each site when the water temperature exceeded $8^{\circ} \mathrm{C}$, which was the water temperature above which successful embryonic development could occur (Johnson 1965). Each site with eggs was revisited weekly to count egg masses until no additional egg masses were recorded in 2 successive visits. Eggs hatched in 13-23 days, depending on the water temperature (Morris and Tanner 1969). The number of egg masses at each breeding site were counted if individual masses could be distinguished. The length, width, and depth of individual masses were measured to estimate their volume. Egg masses that occurred in the same stream but were in separate bodies of water (where larvae could not interact) were considered independent samples.

Only standing water or very slowly moving water was searched for egg masses and adults by walking along the edge of the stream and checking all oxbows, backwaters, pools, marshy areas, and adjacent ponds using a modified form of the basic visual-encounter survey (Scott and Woodward 1994, Thoms et al. 1997). Searches were focused in shallow water $(<30 \mathrm{~cm})$ because Columbia spotted frog egg masses occur in these situations (Turner 1960, Morris and Turner 1969, Hovingh 1993, Munger et al. 1996).

We classified each site as a pond exca vated for livestock or wildlife, gravel pit, dredge tailings, marsh, oxbow, beaver pond, or other. We recorded elevation, surface area of breeding site $\left(\mathrm{m}^{2}\right)$, maxi mum water depth $(\mathrm{m})$, and distance to a permanent stream. Substrate of the pond was identified as mud, cobble, or stone. The percent of water surface area that contained algae, suspended vegetation, and open water were recorded at each site. Ground cover within $2 \mathrm{~m}$ of the pond edge was recorded as the percent of grass, shrub, or rock. The presence of beavers (Castor canadensis Linnaeus) was noted.

\section{Recently Metamorphosed Individuals (Recruitment)}

We selected 54 of the 127 breeding sites based on accessibility and grazing activity to assess frog recruitment; 29 were ungrazed, and 25 were grazed sites. We searched for recently metamorphosed individuals between July and September by walking the perimeter of each breeding site and counting juvenile frogs seen in water or on land. Searches continued at 1week intervals until metamorphs were no longer metamorphosing. The maximum number of recently metamorphosed juveniles at each site was used for the analysis.

In August, we recorded the same habitat characteristics measured during the spring. Water quality variables $(\mathrm{pH}$, conductivity, nitrates, and dissolved oxygen) were measured at each site. Duration and intensity of grazing varied considerably among sites, so evidence of livestock activity was recorded in 3 ways: degree of utilization, number of dung pats, and trampling (hoofprint density). All 3 characteristics were given a rating from 0 to 3 with $0=$ none, 1 $=$ slight evidence, $2=$ moderate evidence, and $3=$ extensive evidence.

To determine abundance of potential predators, we recorded the number of garter snakes observed at ponds on each visit but used the maximum number recorded on any visit as the independent variable. The presence and kind of fish were recorded. We sampled aquatic invertebrates by taking 8 sweeps with a dip net at each site and counting leeches (Hirudinea), giant water bugs (Homoptera: Belostomatidae), diving beetles (Coleoptera: Dytiscidae), and backswimmers (Homoptera: Notonectidae).

\section{Analyses}

Mann-Whitney tests (Conover 1980) were used to compare the number of egg masses, volume of egg masses, number of recently metamorphosed individuals, and ratio of recently metamorphosed individuals per egg mass in grazed and ungrazed sites. Nonparametric Spearman's rank correlations (Conover 1980) were used to determine the relationship between number of egg masses and elevation for all sites and for grazed and ungrazed sites. Simple linear regressions were used to compare: (1) number of egg masses and elevation for grazed and ungrazed sites, (2) mean egg mass volume and elevation for grazed and ungrazed sites, and (3) mean egg mass volume and elevation for sites with $\geq 3$ egg masses at grazed and ungrazed sites. Kruskal-Wallis nonparametric ANOVAs (Conover 1980) were used to compare number of egg masses, mean egg mass volume, number of recently metamorphosed juveniles, and the ratio of recently metamorphosed juveniles per egg mass among pond types. The habitat characteristics that best predicted number of egg masses and abundance of recently metamorphosed juveniles were identified using a stepwise logistic regression using all ponds combined, only grazed ponds, and only ungrazed ponds.

\section{Results and Discussion}

We located 127 Columbia spotted frog breeding sites across a 5-county area in eastern Oregon. Seventy (55\%) ponds were grazed by cattle; the remaining 57 $(45 \%)$ were ungrazed. Thirty-nine percent of the breeding sites were dredge tailing ponds, $24 \%$ were oxbows, $17 \%$ were excavated for livestock or wildlife, $14 \%$ were marshes near streams, $3 \%$ were created by beaver dams, $2 \%$ were in gravel pit ponds, and $1 \%$ was a natural spring-fed pond. Breeding sites were typically small; $92 \%$ had a surface area $<2,500 \mathrm{~m}^{2}$ and only $8 \%$ were $2,500-30,000 \mathrm{~m}^{2}$. Thirtyfour percent of the ponds were $<1 \mathrm{~m}$ deep while the remainder were 1-5 $\mathrm{m}$ deep. All ponds had a fine benthic substrate (mostly mud).

\section{Egg Masses}

The number of egg masses at grazed sites was not statistically different from the number at ungrazed sites (Table 1). Breeding sites occurred between 922 and $1,860 \mathrm{~m}$ in elevation. The elevational distribution of grazed and ungrazed ponds differed primarily because all grazed sites were below 1,500 m. At grazed sites there was a weak, but significant inverse correlation $\left(\mathrm{p}=0.03\right.$, adjusted $\left.\mathrm{r}^{2}=0.06\right)$ between number of egg masses and elevation. At ungrazed sites, a weak but significant positive correlation $\left(\mathrm{p}=0.05, \mathrm{r}^{2}=\right.$ 0.05 ) existed between number of egg 
Table 1. Mean values, standard errors, and ranges of independent and dependent variables measured at Columbia spotted frog breeding ponds in northeastern Oregon, 1997.

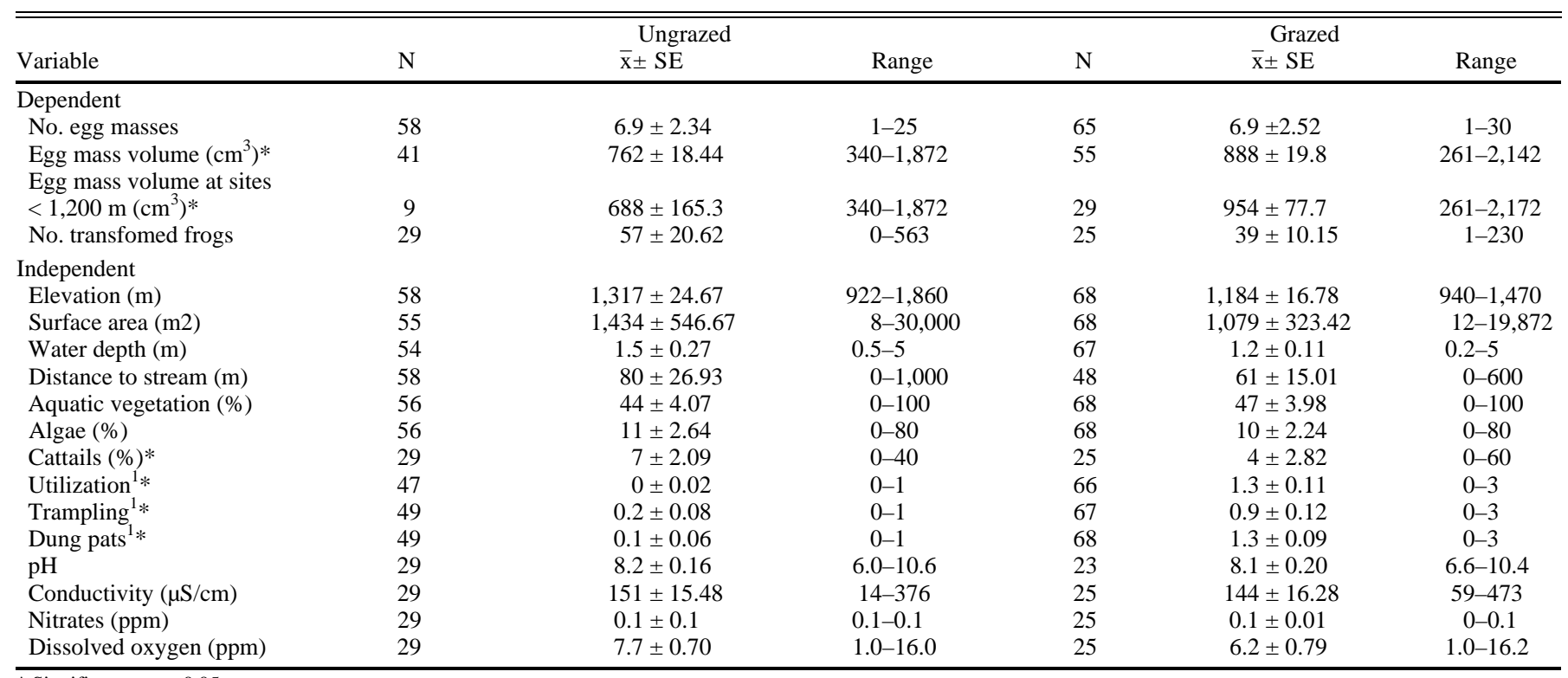

* Significant at $\mathrm{p}<0.05$.

${ }^{1}$ These variables were coded from 0 to 3 , indicating relative abundance of each variable.

masses and elevation. Number of egg masses did not differ among pond types. Egg mass volume differed significantly between grazed and ungrazed sites (MannWhitney U: $Z=-2.07, p=0.04$ ) (Table 1). No relationship existed between mean egg mass volume and elevation for either grazed or ungrazed sites. Because of variability in egg mass volume and at many sites only one egg mass was available to measure, we compared the relationship between mean egg mass volume and elevation at sites where 3 or more egg masses were measured. A significant relationship was displayed between mean egg mass volume and elevation for both grazed $(\mathrm{p}=$ 0.02 , adjusted $r^{2}=0.15$ ) and ungrazed sites $\left(\mathrm{p}<0.01\right.$, adjusted $\left.\mathrm{r}^{2}=0.24\right)$ with volume increasing with elevation. Because egg mass size increased with elevation and more grazed sites were present at lower elevations, we compared egg mass size at all sites and at sites with 3 or more egg masses at or below 1,200 $\mathrm{m}$ and above $1,200 \mathrm{~m}$. The only significant comparison was between grazed and ungrazed sites at or below 1,200 m (Mann-Whitney U: U = $\left.69, \mathrm{U}^{\prime}=192, \mathrm{p}=0.03\right)$.

The larger egg mass volume at grazed sites suggests that grazing did not have a negative effect, in addition to our observation that 6 of the 8 most productive sites ( $\geq 20$ egg masses) were grazed. Because grazed sites were below $1,500 \mathrm{~m}$, we considered the possibility that variation in egg mass volume might be influenced by elevation. The possibility of such a confound- ing factor was rejected because the data showed that egg mass volume increased with elevation. Larger egg masses may reflect larger females (Corn and Fogelman 1984), which could be a result of a more abundant food supply or an older population structure (Turner 1960).

No pond characteristics measured satisfactorily predicted the number of egg masses. The stepwise logistic regression selected elevation, percent aquatic vegetation, and percent open water as able to achieve a maximal predictive value of only $7 \%$ of the total variability.

\section{Recently Metamorphosed Frogs}

Neither the number of recently metamorphosed frogs nor the ratio of recently metamorphosed frogs to number of egg masses was significantly different between the 25 grazed and 29 ungrazed sites (Table 1). There were also no significant differences between grazed and ungrazed sites in water characteristics (dissolved oxygen, nitrates, $\mathrm{pH}$, and conductivity). However, correlation analysis revealed that numbers of recently metamorphosed frogs were inversely correlated with the presence of fishes (Spearman's Rank, $\rho=-0.41, p=$ $0.0028)$ for all sites. Longnose dace (Rhinichthys cataractae dulcis Valenciennes) and rainbow trout (Oncorhynchus mykiss Walbaum) were identified at the breeding sites with fish. Inverse correlations between frog larvae and fish have been demonstrated often (Hayes and Jennings 1988, Bradford 1989,
Bradford et al. 1993) and may be reflected by the inverse correlation between recently metamorphosed frogs and fish in this study.

Numbers of recently metamorphosed frogs were positively correlated with garter snakes (Spearmans's Rank, $\rho=$ $0.52, \mathrm{p}<0.01)$ for all sites. The common garter snake (Thamnophis sirtalis Linnaeus) and the wandering garter snake (T. elegans vagrans Baird and Girard) were present in about equal proportions at the ponds. Garter snakes were observed preying on recently metamorphosed frogs at several sites. Most of the predation by garter snakes occurred after or during metamorphosis, and after we had obtained our highest counts of frogs. It is likely that ponds with high numbers of metamorphosing frogs attracted more snakes than ponds with low numbers of frogs.

In comparisons of habitat variables between grazed and ungrazed sites, only percent cattails (Mann-Whitney $\mathrm{U}: \mathrm{Z}=$ 2.37, $\mathrm{p}=0.02)$, utilization $(\mathrm{Z}=-4.55, \mathrm{p}<$ $0.01)$, trampling $(Z=-4.97, p<0.01)$, and dung pat density $(Z=-5.01, p<0.01)$ were significantly different (Table 1). A correlation analysis revealed that percent of cattails was positively correlated with pond size (Spearman's Rank, $\rho=0.37, \mathrm{p}<0.01$ ).

Selected habitat characteristics were successful predictors of the abundance of recently metamorphosed frogs. For all 54 ponds, 5 variables were retained in the analysis with percent aquatic vegetation explaining $25 \%$ of the variability; the remaining 4 variables (dissolved oxygen, 
elevation, utilization, and pond depth) explained another $16 \%$ of the variability. In ungrazed ponds, 6 variables (fish, percent aquatic vegetation, elevation, percent of rock on shore, dissolved oxygen, and conductivity) explained $65 \%$ of the variability. In grazed ponds, percent aquatic vegetation explained $35 \%$, and dissolved oxygen explained $30 \%$ of the variability. Percent aquatic vegetation and dissolved oxygen were the only variables that were retained in all models (combined, grazed, and ungrazed).

Percent aquatic vegetation, dissolved oxygen, and presence of fish all contributed significantly to predict the abundance of recently metamorphosed frogs, which may reflect a fundamental aquatic vegetation effect. Aquatic vegetation is known to provide shelter for frog larvae and metamorphs from fish and other predators (Licht 1969). Levels of dissolved oxygen are directly linked to coverage of aquatic vegetation (Carpenter and Lodge 1986).

\section{Conclusions}

These data failed to reveal that grazing had a negative effect on reproduction and recruitment of the Columbia spotted frog in northeastern Oregon. The high variability in the results of this study may be linked to the breadth of the grazing variable encompassing a broad range of conditions in landform features, water quality, vegetation, predators, and invertebrates. Future studies need to pay particular attention to measuring grazing intensity and timing to detect potential effects on Columbia spotted frogs.

\section{Literature Cited}

Allen, D.R. and C.B. Marlow. 1994. Shoot population dynamics of beaked sedge following cattle grazing. J. Range Manage. 47:65-69.

Bohn, C.C. and J.C. Buckhouse. 1986. Effects of grazing management on streambanks. Trans. N. Amer. Wildl. and Natur. Resources Conf. 51:265-271.

Bradford, D.F. 1989. Allotropic distribution of native frogs and introduced fishes in the high Sierra Nevada lakes of California. Copeia 1989:775-778.

Bradford, D.F., D.M. Graber, and F. Tabatabai. 1993. Isolation of remaining populations of the native frog, Rana muscosa, by introduced fishes in Sequoia and Kings Canyon National Parks, California. Conserv. Biol. 7:882-888.
Carpenter, S.R. and D.M. Lodge. 1986. Effects of submersed macrophytes on ecosystem processes. Aquat. Bot. 26:341-370.

Conover, W.J. 1980. Practical nonparametric statistics. 2 nd ed. John Wiley \& Sons, New York, N.Y

Corn, P.S. and J.C. Fogelman. 1984. Extinction of montane populations of the northern leopard frog (Rana pipiens) in Colorado. J. Herpetology 18:147-152.

Ferguson, D.E. 1952. The distribution of amphibians and reptiles of Wallowa County, Oregon. Herpetologica 8:66-68.

Ferguson, D.E. 1954. An annotated list of the amphibians and reptiles of Union County, Oregon. Herpetologica 10:149-152.

Ferguson, D.E., K.E. Payne, and R.M. Storm. 1958. Notes on the herpetology of Baker County, Oregon. Great Basin Natur. 18:63-65.

Green, D.M. and J.B. Kauffman. 1995. Succession and livestock grazing in a northeastern Oregon riparian ecosystem. J. Range Manage. 48:307-313.

Green, D.M., H. Kaiser, T.F. Sharbel, J. Kearsley, and K.R. McAllister. 1997. Cryptic species of spotted frogs, Rana pre tiosa complex, in western North America. Copeia 1997(1):1-8.

Hayes, M.P. 1997. Status of the Oregon spotted frog (Rana pretiosa sensu stricto) in the Deschutes Basin and selected other systems in Oregon and north eastern California with a rangewide synopsis of the species' status. Final report to Nature Conserv., Portland, Ore.

Hayes, M.P. and M.R. Jennings. 1988. Habitat correlates of distribution of the California red-legged frog (Rana aurora draytonii) and the foothill yellow-legged frog (Rana boylii): implications for management, p 144-158. In Proc. Sym. on the management of amphibians, reptiles, and small mammals in North America. USDA For. Serv., Gen. Tech. Rep. GTR-RM-166, Fort Collins, Colo.

Horsup, A., C. James, and G. Porter. 1993. Vertebrates of dry rainforest of south and mideastern Queensland. Memoirs of the Queensland Museum 34:215-228.

Hovingh, P. 1993. Aquatic habitats, life history observations, and zoogeographic considerations of the spotted frog (Rana pretiosa) in the Tule Valley, Utah. Great Basin Natur. 53:168-179.

Jennings, M.R. and M.P. Hayes. 1994. Amphibian and reptile species of special concern in California. Final report to Calif. Dept. Fish and Game, Rancho Cordova, Calif.

Johnson, O.W. 1965. Early development, embryonic temperature tolerance, and rate of development in Rana pretiosa luteiventris Thompson. Ph.D. Thesis, Oregon State Univ. Corvallis, Ore.

Licht, L.E. 1969. Comparative breeding biology of the red-legged frog (Rana aurora aurora) and the western spotted frog (Rana pretiosa pretiosa) in south western British Columbia. Can. J. Zool. 47:1287-1299.
Kauffman, J.B., W.C. Krueger, and M. Vavra. 1983. Impacts of cattle on streambanks in northeastern Oregon. J. Range Manage. 36:683-685.

Morris, R.L and W.W. Tanner. 1969. The ecology of the western spotted frog, Rana pretiosapretiosa Baird and Girard, a life history study. Great Basin Natur. 29:45-81.

Mosconi, S.L. and R.L. Hutto. 1982. The effect of grazing on land birds of a western Montana riparian habitat, p 221-233. In: Wildlife-livestock relationships symposium: proc. 10. Univ. of Idaho, Forest, Wildlife and Range Exp. Sta., Moscow, Ida.

Munger, J.C., M. Gerber, M. Carroll, K. Madrid, and C. Peterson. 1996. Status and habitat associations of the spotted frog Rana pretiosa in southwestern Idaho. Tech. Bull. No. 96-1. Idaho Bureau Land Manage.

Munger, J.C., L. Heberger, D. Logan, W. Peterson, L. Mealy, and M. Cauglin. 1994. A survey of the herpetofauna of the Bruneau Resource Areas, with focus on the spotted frog, Rana pretiosa. Bureau Land Management Tech. Bull.

Platts, W.S. 1981. Influence of forest and rangeland management on anadromous fish habitat in western North American: effects of livestock grazing. USDA For. Ser., Gen. Tech. Rep. GTR-PNW-124, Portland, Ore.

Roath, L.R. and W.C. Krueger. 1982. Cattle grazing influence on a mountain riparian zone. J. Range Manage. 35:100-103.

Scott, N.J., Jr. and B.D. Woodward. 1994. Surveys at breeding sites. p. 118-125. In: W.R. Heyer, M.A Donnelly, R.W. McDiarmid, and others (eds.). Measuring and monitoring biological diversity: Standard methods for amphibians. Smithsonian Institution Press, Washington, D.C.

Sedgwick, J.A. and F.L. Knopf. 1991. Prescribed grazing as a secondary impact in a western riparian floodplain. J. Range Manage. 44:369-373.

Thoms, C., C.C. Corkran, and D.H. Olson. 1997. Chapter 3: Basic amphibian survey for inventory and monitoring in lentic habitats, p. 35-46. In: D.H. Olson, W.P. Leonard, R.B. Bury (eds.), Sampling amphibians in lentic habitats. Northwest Fauna No. 4.

Thomas, J.W., C. Maser, and J.E. Rodiek. 1979. Wildlife habitats in managed rangelands: the Great Basin of southeastern Oregon: riparian zones. USDA For. Serv., Gen. Tech. Rep. GTR-PNW-80, Portland, Ore.

Turner, F.B. 1960. Population structure and dynamics of the western spotted frog, Rana p. pretiosa Baird \& Girard, in Yellowstone Park, Wyoming. Ecol. Monogr. 30:251-278. 